\title{
Treatment of fear memories: interactions between extinction and reconsolidation
}

\author{
NATÁlia G. FIORENZA ${ }^{1}$, DAGIELI SARTOR ${ }^{1}$, JOCIANE C. MYSKIW ${ }^{1}$ and IVÁN IZQUIERDO ${ }^{1,2}$ \\ ${ }^{1}$ Centro de Memória, Instituto de Pesquisas Biomédicas, Pontíficia Universidade Católica do Rio Grande do Sul (PUCRS), \\ Av. Ipiranga, 6690, $2^{\circ}$ andar, 90610-000 Porto Alegre, RS, Brasil \\ ${ }^{2}$ Instituto Nacional de Neurociência Translacional, Conselho Nacional de Desenvolvimento Científico \\ e Tecnológico (CNPq) no Centro de Memória, Instituto do Cérebro \\ Manuscript received on June 6, 2011; accepted for publication on September 8, 2011
}

\begin{abstract}
Retrieval labilizes memory traces and these gates two protein synthesis-dependent processes in the brain: extinction, which inhibits further retrieval, and reconsolidation, which may enhance retrieval or change its content. Extinction may itself suffer reconsolidation. Interactions among these processes may be applied to treatments of fear memories, such as those underlying post-traumatic stress disorders.
\end{abstract}

Key words: extinction learning, fear memories, memory, post-traumatic stress disorder, reconsolidation.

\section{OBJECTIVES}

Posttraumatic stress disorder (PTSD) has been treated for a number of years by means of Pavlovian extinction, often under the name of "exposure". Recently there have been several basic findings on how to modify extinction by behavioral means. This may result in its enhancement, and this should increase its power to treat fear memories, particularly those underlying PTSD. Here we will briefly revise this topic, which is both of academic and clinical interest.

\section{INTRODUCTION}

Memories may be modified in many ways after their consolidation. The two best known and most widely studied ways are extinction and reconsolidation, which change memories quantitatively and, in the case of reconsolidation, sometimes also qualitatively. Of course, the mere quantitative alteration of any given memory or group of memories can modify cognition very extensively: Norberto Bobbio (1909-2004) observed that

Correspondence to: Iván Izquierdo

E-mail: izquier@terra.com.br "we are what we remember" (Izquierdo 2011). It is impossible to be what we do not remember; we live, think, perceive and make plans for the future based on memories, both for the next few seconds and for the distant future. And if we change what we remember, we certainly will change what we are and thereby what we can be.

The nonreinforced retrieval of long-tem memories reactivates the previously consolidated traces of those memories and puts them in a labile state, in which they may undergo two opposite protein synthesis-dependent processes: extinction (Pavlov 1956, McGaugh 2000, Izquierdo 2011) and reconsolidation (Sara 2000, Izquierdo et al. 2008, Quirk et al. 2010, Bevilaqua et al. 2010). Extinction was originally described by Pavlov a century ago (Pavlov 1956). Reconsolidation has been recognized relatively recently (Sara 2000, Nader et al. 2000). Both processes are triggered during the first retrieval session after the original consolidation of memories (Sara 2000, Vianna et al. 2001, Cammarota et al. 2005, Izquierdo et al. 2008, Quirk et al. 2010), and have been described in a number of species and learn- 
ing situations. Reconsolidation mechanisms apparently are activated somewhat earlier than extinction processes in the central nervous system of crabs (Pérez-Cuesta et al. 2007). They cannot be activated after extinction has already been initiated because by then the extinction process has already begun to take its toll, which it does right after it starts (Izquierdo et al. 1965, Cammarota et al. 2005, Izquierdo 2011).

Extinction consists of the inhibition of retrieval of previously consolidated memories (Pavlov 1956, Rescorla 2001, Izquierdo 2011), and is widely used in the treatment of fear memories, such as that underlying post-traumatic stress disorders (Beckett 2002, Davis et al. 2006a, Izquierdo et al. 2008, Quirk et al. 2010). The fading away of memories not yet consolidated, such as those that last only a few minutes or hours, may be viewed as short-term extinction (Cammarota et al. 2005), but it is not clear whether it is part of the same phenomenon. Short-term memories may just fade away because they are not accompanied and substantiated by brain protein synthesis (Quevedo et al. 1999, Igaz et al. 2002).

Reconsolidation is supposed to reaffirm memories that could otherwise be lost (Sara 2000, Nader et al. 2000, Rossato et al. 2006, 2010), and may allow incorporation of additional information into them (Forcato et al. 2010, Schiller et al. 2010) which is, by the way, commonplace in retrieval sessions (Izquierdo 1984); actually, multi-trial learning consists of new learnings on top of retrievals, repeatedly. Such learning is in fact the one used for educational purposes all over the world. Extinction is a form of learning (Rescorla 2001, Quirk et al. 2010, Izquierdo 2011), whereas reconsolidation is instead a property of retrieval (Izquierdo et al. 2008, Bevilaqua et al. 2010), which might or might not involve the addition of new learning. Extinction is directly observable (Pavlov 1956, Quirk et al. 2010, Bevilaqua et al. 2010, Izquierdo 2011); reconsolidation must be inferred from observations that post-retrieval treatments, such as protein synthesis inhibition or other treatments in the amygdala (Nader et al. 2000) or hippocampus (Debiec et al. 2002, Rossato et al. 2006, 2010, Amaral et al. 2007), reduce retrieval in a subsequent session.
Extinction is not forgetting: responses either recover spontaneously if the extinction trials are delayed, or return in full if just one reinforcement is given (Pavlov 1956, Izquierdo et al. 1965, Rescorla 2001). This means that they remain encoded in the brain during extinction, but are not expressed. Reconsolidation is not a recapitulation or a repetition of consolidation: the time course of both processes is different, and so are several of the brain structures and molecular processes involved (Quirk et al. 2010, Bevilaqua et al. 2010, Izquierdo 2011).

Knowledge about extinction and reconsolidation has accumulated in recent years, but their possible interactions have been less studied. Recent findings suggest that these interactions could be of clinical significance in the treatment of fear memories, such as those of PTSD.

Abundant evidence shows that both extinction and reconsolidation are initiated by retrieval (Vianna et al. 2001, Szapiro et al. 2003, Cammarota et al. 2005). Indeed, this is particularly evident in extinction, whose mechanisms in its early phase in the first test session after the last reinforced trial have been much better worked out than those of reconsolidation, particularly in the hippocampus (Vianna et al. 2001, Cammarota et al. 2005). Several of the biochemical changes that underlie retrieval in this structure, such as the activation of dopaminergic and noradrenergic receptors, protein kinase A, extracellularly regulated kinases (Barros et al. 2000) and even the synthesis of pCREB (phosphorylated cyclic AMP response element binding protein), long held as a crucial step in the laying down of longterm potentiation and memories (Bernabeu et al. 1997), may at the same time express a post-retrieval event (Viola et al. 2000) and substantiate the biochemical changes of extinction (Szapiro et al. 2002). Both extinction and reconsolidation are pharmacologically affected by a variety of drugs given into the hippocampus, the basolateral amygdala, and/or the ventromedial prefrontal cortex immediately after retrieval (Izquierdo et al. 2008, Quirk et al. 2010, Bevilaqua et al. 2010). While extinction can take place any time after the original learning (hours, days, months, years; Pavlov 1956) and regardless of how many times the animals have been exposed to it before (Izquierdo et al. 1965), reconsoli- 
dation can only be obtained if the retrieval session that triggers it takes place shortly after the original training (a few hours; Monfils et al. 2009; or at most a few days; Milekic and Alberini 2002). Susceptibility of reconsolidation to protein synthesis inhibitors given into the amygdala or hippocampus decreases as the time between training and recall increases (Milekic and Alberini 2002), and so does the reconsolidating effect of retrieval. As will be seen, this property of retrieval has been recently put to use in the design of a new technique to promote a better extinction (Schiller et al. 2010).

\section{THE USE OF EXTINCTION IN THE TREATMENT OF FEAR-MOTIVATED LEARNING}

In the first half of the past century the most studied types of fear-motivated behaviors were the phobic states, and the prevalent explanation of these states was Pierre Janet's theory of a constitutional lowering of brain energy, somehow related to hysteria (Janet 1906). In 1909, Freud described the case of Little Hans, a 5-year old boy with a strong Oedipal Complex and an intense fear and rejection of his father, from whom he feared castration. This marked for Freud a turning point in his studies and thinking about fear-motivated disorders (Nemiah 1985). Phobias were then seen as the major and prototypical fear-motivated disorder. Over the years, the family of disorders generated by fear learning was perceived as englobing many more conditions than just the phobic disorder, and today, among its various members, PTSD is seen as the most serious one (Sher and Vilens 2010).

Note that in this very brief historical survey we made reference to Pierre Janet's idea of fear-motivated behaviors being related to hysteria, and to Freud's early belief that such behaviors derived from the symbolic fear of castration. Gains or losses of brain energy, hysteria and symbolic fear of castration are scarce if ever mentioned in today's more biologically oriented Psychiatry or Neuroscience literature, except for historical reasons, like here. Actually, hysteria and the symbolic fear of castration have all but disappeared as clinical entities in modern Psychiatry.

About 100 years ago, panic began to be differentiated from the phobias. Until then, both were pooled together: it was customary to say that exposure to certain objects or situations caused panic. From the 1960's through the 1980's pharmacological treatments differentiated them further: panic responds readily to benzodiazepines and phobias do not. Over the years, two major World Wars and a long succession of other catastrophes made the PTSD recognizable as the most serious disease of the family of fear-motivated disorders. The consequences of natural and man-made disasters on mental health began to be seen under the modern psychiatric understanding of fear-related pathologies, which led to the recognition of PTSD in those terms. It is very significant that the front cover of one the most recent major books on PTSD (Sher and Vilens 2010) features a picture of soldiers at war; in many countries, war is a major cause of PTSD; in others, it is earthquakes, tsunamis, floods, landslides or other natural or man-made disasters. For most, however, the major source of PTSD is individual, rather than collective experiences: rape, torture, accidents, major illnesses, humiliations, etc.

At some point back in the 1920's Freud and his disciple, Sandor Ferenczi, found it impossible to treat phobias with psychoanalytic techniques, let alone more serious fear-motivated syndromes, and turned to Pavlovian extinction, which Freud called "habituation". They applied it with success from the very beginning to the treatment of phobias (Nemiah 1985). It is still the treatment of choice today.

In the last 30 years, PTSD was recognized as the most serious and a very prevalent fear-motivated disorder (Beckett 2002, Sher and Vilens 2010). The disorder had long been known, but its establishment as a definite clinical entity took place in the past few decades. Pavlovian extinction began to be applied with success to the treatment of PTSD (Beckett 2002, Davis et al. 2006a). The clinical procedure involves the exposure of the patient to the feared object or context, or to a close enough representation of it (photographs, etc.) without any danger, while the therapist comforts the client in order to reduce anxiety. In clinical settings, extinction became known by a variety of different names (exposure, flooding, desensitization, etc.) because of the strong resistance of most North American and some European Psychologists and Psychiatrists to use Pavlovian terminology. Freud himself called it "habituation", which in Pavlovian terminology and in Neuroscience as a whole means a different thing (Pavlov 1956, Izquierdo 2011). 
Habituation is the waning of an unconditioned response with repetition, whereas extinction is the waning of a conditioned response. The systems and brain sites involved in habituation are different from those involved in extinction (Izquierdo 2011). Freud was a contemporary of Pavlov and saw him as a competitor in Psychological or Psychiatric theory and terminology. Today, in turn, many psychiatrists and psychologists reject Freudian concepts and terminology, and a large number of them belong to a school advocating Cognitive Therapy (Izquierdo 2006) as an approach to the treatment of mental disturbances quite different from Psychoanalysis, be it Freudian or non-Freudian. They consider the "exposure" therapy as belonging to the realm of Cognitive Therapy. Perhaps inadvertently Freud himself laid the foundation of Cognitive Therapy back in the 1920's with his introduction of extinction for the treatment of phobias; even he thought it would be better to use it under a different name (Izquierdo 2006).

\section{WHY, UNLIKE IN MOST OTHER PSYCHIATRIC DISORDERS, DRUGS ARE LITTLE USED TO TREAT PTSD OR PHOBIAS}

The possibility of erasing memories rather than just inhibiting their expression, has been entertained since McGaugh and coworkers first showed drug-induced inhibition of memory consolidation by posttraining treatments in the 1950's (see McGaugh 2000) and Gold, Izquierdo, Bohus and their coworkers described the inhibition of retrieval by pre-test treatments in later years (Izquierdo 1984). In some cases the inhibition of retrieval is due to a drug-induced mismatch between the brain state(s) prevalent at the time of consolidation and the state(s) prevalent at the time of testing: the best studied case is when opioids are given posttraining, but not at the time of testing, a situation in which various brain regions and neurotransmitter systems are activated (Izquierdo 1984, Krajehpour and Zarrindast 2009). Posttraining "amnestic" treatments, however, prevent or cancel the on-going recording of memories rather than cause a real amnesia, humans who receive them perceive them as amnestic because they cannot interpret a shortlived loss of recording in any other manner (Izquierdo 2011). It is of course certainly possible to cancel memories in humans by posttraining or pre-test treatments: the amnesic effect of anesthesia, head trauma or electroconvulsive shock has been known for years (McGaugh 2000). However posttraining and pre-test treatments are seriously hampered by their time-locked nature. For example, it has been shown that the posttraining administration of $\beta$-noradrenergic receptor antagonists like propranolol can cause "retrograde amnesia" for many if not all kinds of memory, first in rodents (see McGaugh 2000) and more recently in humans (Orr et al. 2006). The same happens with sevoflurane and other general anesthetics (Alkire et al. 2008), a class of drugs that has long been known to induce posttraining amnesia and that are difficult to handle safely by the lay people. However, it is obviously impractical to use any of the two treatments since people do not walk about with propranolol or sevoflurane in their pockets to use immediately after acquiring a traumatic memory, which is when these treatments act (Quirk et al. 2010, Bevilaqua et al. 2010).

Likewise, many treatments are very effective in blocking retrieval, sometimes permanently (see Izquierdo 1984) when given shortly before a retention test session; perhaps physiologically the most important are cortisol and other glucocorticoids (De Quervain 2006, De Quervain et al. 2011). Actually, the effect of several of these posttraining amnestic treatments, like the anesthetic sevofluorane, is mediated by an interference with $\beta$-noradrenergic receptors in the basolateral amygdala and perhaps elsewhere, which mediate retrieval, and, in addition, or related to that, by a reduction of blood flow in the temporal lobe (De Quervain et al. 2011). But, again, people simply do not carry corticoids or sevofluorane to use in anticipation of a traumatic episode that is yet to come. Actually, many episodes are traumatic because they happen by surprise.

Further, many consider that erasing a memory, no matter how bad that memory may be, is ethically improper (see Bevilaqua et al. 2010 for a discussion of this point); even though this possibility so far has proven to be largely theoretical for the practical reasons discussed in the preceding paragraph. So far, in effect, the selective erasure of one or a few given memories has been only a subject of fiction. It can be counter argued that there is no ethical reason that can justify preserving the memory of a rape or of a session of torture if it can be effectively eliminated (Bevilaqua et al. 2010, Izquierdo 
2011), people can always get information about rape or torture without having to retrieve recurrent flashbacks of their own sad experiences with them.

Thus, neither posttraining nor pre-test pharmacological treatments are of much practical value in alleviating PTSD or related syndromes, including the phobias. Since no drug effects outside the post-event or pre-retrieval periods are known that may inhibit traumatic or otherwise unwanted memories, there really is no appropriate way to treat fear-motivated syndromes with drugs, aside from panic attacks. These do pertain, however, to a different class of anxiety disorders, inasmuch as, contrary to phobias or certainly PTSD, they are not linked to any traceable memory in particular or to a given stimulus or event. Panic happens on its own, unpredictably, and can be treated with benzodiazepines, or a variety of anxiolytic or antidepressant agents administered once it starts or, in those cases in which it recurs preferentially around a given hour of the day, just before that hour, daily.

The impossibility or implausibility of using drug treatments for PTSD or phobias makes the use of extinction therapy not only desirable, but also mandatory (Beckett 2002, Davis et al. 2006a, Izquierdo et al. 2008, Quirk et al. 2010). A few authors have recommended to use it together with corticoids (De Quervain 2006) or, more rarely, with benzodiazepines or cycloserine, a drug that acts on the glycine site of glutamate NMDA receptors (Ressler et al. 2004, Davis et al. 2006b). Cycloserine, for this reason, enhances extinction when given into the hippocampus or the basolateral amygdala, two structures that participate in the genesis of extinction through NMDA receptors at least in the hippocampus (Szapiro et al. 2003). Much evidence suggests a similar biochemical chain of events in the hippocampus and basolateral amygdala both for consolidation and extinction, and to an extent by reconsolidation (Rossato et al. 2007, Duvarci et al. 2008). This suggests the possibility that the behavioral outcome, in response to the two main post-retrieval processes, extinction and reconsolidation, may not depend as much on what biochemical pathways are activated, but on where in the brain they are activated in each case; i.e., whether it is predominantly in the hippocampus, or in the basolateral amygdala, or elsewhere. The brain areas that participate in consolidation and extinction, except for the hippocampus and amygdala, are not the same, even though the neurochemical systems involved in each behavioral process are similar in these two areas (Myskiw et al. 2010).

Anxiolytics have been lately sporadically recommended for the treatment of PTSD, but their use has yet to give any satisfactory result comparable to those of extinction (see Sher and Vilens 2010).

Several studies have suggested a key role of hippocampal endogenous cannabinoids in the extinction of aversive (Kamprath et al. 2006), but not appetitive learning (Hölter et al. 2005) in animal models (see also Lafenêtre et al. 2007, Heifets and Castillo 2009). The fact that cannabinoids are not available legally in many countries hinders the possible postulation of their use in clinical settings in order to enhance extinction. A role for endocannabinoids in the consolidation via mTOR protein synthesis stimulation has been also suggested (Puighermanal et al. 2009). There is a recent rather comprehensive review on the role of cannabinoids in long-term synaptic plasticity (Heifets and Castillo 2009).

\section{INTERACTIONS BETWEEN EXTINCTION AND RECONSOLIDATION, AND THEIR POSSIBLE APPLICATION TO PTSD THERAPY}

The widely accepted use of extinction for the treatment of fear-motivated disorders has generated much research recently on how it can be enhanced by making use of what we already know about its interaction with mere retrieval and with reconsolidation.

Monfils et al. (2009) recently submitted rats to a retrieval session of fear learning shortly after acquisition and, once the memory of the fear was labilized, exposed them to formal extinction of the task. The intercalated "extra" retrieval session was of course a session of extinction, actually the first of a series, but it was given within the 6 hours "reconsolidation" window, a time after the original training in which the memory trace was labilized. This pre-exposure or "reminder" procedure facilitated extinction. The data suggest that this procedure should be useful to enhance the therapeutic effect of extinction in fear-motivated tasks, which has been used for years in the treatment of the posttraumatic stress disorder (Beckett 2002, Davis et al. 2006a, 
Quirk et al. 2010). Since this treatment is not fail-safe and the obvious alternative, the pharmacological inhibition of reconsolidation, is difficult, if at all possible, in humans, the "trick" proposed by Monfils et al. (2009) of interposing an isolated retrieval session at a time of memory labilization before the formal extinction procedure in order to increase the susceptibility of the memory to extinction seems very sound. Before the notion of memory labilization by retrieval took hold (Sara et al. 2000, Nader et al. 2000), of course the extra trial presented before the formal extinction would have been viewed as just one more extinction trial, i.e., actually the first of the extinction series (Pavlov 1956).

In another paper, Schiller et al. (2010) updated an originally fearful memory with non aversive information during the reconsolidation window in humans and successfully erased the fearful memory for at least one year without affecting other memories. Actually, this may be viewed as one form of inducing extinction, in extinction, the original response is actually superseded by another response, namely, that of specifically inhibiting the original response (Pavlov 1956, Rescorla 2001, 2004). Both in the memory update and in the pre-exposure procedure an obvious requisite is that the labilization session is carried out shortly after acquisition of the memory, which in real-life post-traumatic stress is of course not always possible.

Recently, García de la Torre et al. (2010) and Rossato et al. (2010) reported that extinction itself, being one form of learning, can be subjected to reconsolidation in at least two different tasks in rats. Both groups showed that the infusion of anisomycin into selected brain structures right after the first extinction trial of a series hindered extinction performance in subsequent trials. García de la Torre et al. (2010) studied conditioned taste aversion and infused the protein synthesis inhibitor into the insular cortex. Rossato et al. (2010) studied inhibitory avoidance and infused the anisomycin into the dorsal hippocampus. Each of these brain areas is specifically involved both in the consolidation and in the extinction of the respective behaviors. This suggests the possibility of yet another form of improving the extinction of fear memories indicates an important behavioral property of extinction that had not been previously described (Rossato et al. 2010), and is in line with the procedures advocated by Monfils et al. (2009) and Schiller et al. (2010) for the inhibition of the recall of fear.

It must be borne in mind, however, that a recent study has shown that, at least for the inhibitory avoidance task, the array of brain structures involved in consolidation are not necessarily the same that is involved in extinction (Myskiw et al. 2010), which is important for understanding the physiology of both processes.

\section{POSSIBLE AND IMPOSSIBLE MECHANISMS OF EXTINCTION-RECONSOLIDATION INTERACTION}

Some evidence suggests that the areas of the brain involved in the consolidation and reconsolidation of several memories may not be the same, which opens possibilities for interactions among all these brain processes mediated by a diversity of brain connections, and there might be differences in the interactions between retrieval with or without updating, for example; after a little or a lot of extinction (García de la Torre et al. 2010). Interestingly, both mRNA and ribosomal protein synthesis in the hippocampus (Igaz et al. 2002, Rossato et al. 2007) and in the basolateral amygdala (Nader et al. 2000, Duvarci et al. 2008) are needed for consolidation (Duvarci et al. 2008), extinction (Vianna et al. 2001) and reconsolidation (Nader et al. 2000). Thus, the different behavioral outcomes of these processes must rely on other parameters, most probably on the interactions between these two structures and on their connections with others.

Evidence indicates a role for the hippocampus (Debiec et al. 2002, Ji and Maren 2007, Myskiw et al. 2010) and the basolateral amygdala (Nader et al. 2000, Likhtik et al. 2008) in the generation of both extinction (Myskiw et al. 2010, Likhtik et al. 2008) and reconsolidation (Nader et al. 2000, Rossato et al. 2006, 2010). In addition to these two brain structures, a wealth of evidence points to a key role of the ventromedial prefrontal cortex in extinction (Milad and Quirk 2002, Milad et al. 2007), but not in reconsolidation. In extinction in humans, this role is suggested by functional magnetic resonance (fMRI) observations during extinction. Reconsolidation studies using fMRI have either not been performed or are unreliable. The fMRI studies show an increased blood flow in the ventromedial 
prefrontal cortex together with an inhibition of the basolateral amygdala and/or the hippocampus. In animals, the role of specific molecular mechanisms in both structures has been rather widely explored in recent years using localized intra-hippocampal and/or intra-amygdala microinfusions of protein synthesis inhibitors and/or drugs known to either stimulate or inhibit selected enzymes of signaling pathways (Bernabeu et al. 1997, Barros et al. 2000, Myskiw et al. 2010) or some neurotransmitter antagonists (Barros et al. 2001, Krajehpour and Zarrindast 2009).

While the findings on human fMRI, on protein synthesis inhibition or even on blockade of gene expression are less punctiform than the findings on drugs acting on a specific enzyme or receptors, some of them can be taken to suggest at least brain areas and connections between brain areas that are involved in extinction or reconsolidation, and may be taken to suggest sequential relationships between the two cognitive processes (Cammarota et al. 2002, Bevilaqua et al. 2010). For example, in the crab Chrysmagnatus possibly the same brain region controls first the beginning of reconsolidation processes and then, after a few seconds, that of extinction mechanisms (Pérez-Cuesta et al. 2007). There is no indication that anything of this sort may occur in mammals. Experiments in rats suggest, instead, the initiation of extinction directly at the time of retrieval using some of the mechanisms that underlie or are used in retrieval.

\section{CONCLUSION}

So, recent advances in the understanding of the interactions among retrieval-dependent processes (labilization of the trace, reconsolidation and extinction) have produced potentially useful additions to the time-honored use of extinction (often under the name of exposure therapy; Beckett 2002, Quirk et al. 2010, Bevilaqua et al. 2010) in the treatment of fear memories. The term "exposure" is used as a synonym or a disguise of the old Pavlovian term, extinction (Pavlov 1956). Unfortunately, it is usually impossible either to predict when a traumatic event will actually happen or to carry the drug along at all times in case one such event may happen. These logistic reasons have prevented the development of any appropriate medication for the treatment or prevention of PTSD and related syndromes. An al- ternative, to be explored in the next few years appear to be the use of some drugs as adjuncts to extinction therapy. D-cycloserine is the most promising such drug so far. Cannabinoids and corticoids may be second or third choices at this stage.

\section{RESUMO}

A evocação labiliza os arquivos de memória, e isto permite dois processos dependentes de síntese protéica no cérebro: a extinção, que inibe a evocação ulterior, e a reconsolidação, que pode aumentar a evocação ou mudar seu conteúdo. A extinção pode por sua vez sofrer reconsolidação. Interações entre estes dois processos podem ser aplicados ao tratamento das memórias de medo, tais como aquelas em que se baseia o estresse pós-traumático.

Palavras-chave: aprendizado de extinção, memórias de medo, memória, transtorno de estresse pós-traumático, reconsolidação.

\section{REFERENCES}

Alkire Mt, Gruver R, Miller J, McReynolds JR, HAHN EL AND CAHILL L. 2008. Neuroimaging analysis of an anesthetic gas that blocks human emotional memory. Proc Natl Acad Sci USA 115: 1722-1727.

AmAral OB, Luft T, CAMMAROTA M, IzQuiERdo I AND ROESLER R. 2007. Temporary inactivation of the dorsal hippocampus induces a transient impairment in retrieval of aversive memory. Behav Brain Res 180: 113-118.

Barros DM, IzQuierdo LA, Mello e Souza T, ArDENGHi P, PEREIRA P, MEDINA JH AND IZQUiERdo I. 2000. Molecular signaling pathways in the cerebral cortex are required for retrieval of one-trial avoidance learning in rats. Behav Brain Res 114(1-2): 183-192.

Barros DM, Mello e Souza T, De David T, Choi H, Aguzzoli A, Madche C, Ardenghi P, Medina JH AND IZQUIERDO I. 2001. Simultaneous modulation of retrieval by dopaminergic $\mathrm{D}(1)$, beta-noradrenergic, serotonergic-1A and cholinergic muscarinic receptors in cortical structures of the rat. Behav Brain Res 124: 1-7.

Beckett WS. 2002. Post-traumatic stress disorder. New Eng J Med 346: 130-132.

Bernabeu R, Bevilaqua L, Ardenghi P, Bromberg E, Schmitz PK, BIANCHIN M, IZQUiERdo I AND MEDINA JH. 1997. Involvement of hippocampal D1/D5 receptor - cAMP signaling pathways in a late memory consolidation phase of an aversively-motivated task in rats. Proc Natl Acad Sci USA 94: 7041-7046. 
Bevilaqua lM, Cammarota M, Medina JH and IZQUIERdo I. 2010. Extinction. In: SHER L AND VILENS A (Eds), Neurobiology of Posttraumatic Stress Disorder. New York: Nova Publishers, p. 309-330.

Cammarota M, Bevilaqua LR, Barros DM, Vianna MRM, IZQUiERdo LA AND MEdinA JH. 2002. Retrieval and the extinction of memory. Cell Mol Neurobiol 256: $465-474$.

Cammarota M, Bevilaqua LR, Rossato Ji, Ramírez MR, MEdinA JH AND IzQUIERdo I. 2005. Relationship between short- and long-term memory and short- and long-term extinction. Neurobiol Learn Mem 84: 25-32.

Davis M, Myers KM, ChHatwal J And Ressler KJ. 2006a. Pharmacological treatments that facilitate extinction of fear: relevance to psychotherapy. NeuroRx 3: 82-96.

DAVIS M, RESSLER K, ROTHBAUM BO AND RICHARDSON R. 2006b. Effects of D-cycloserine on extinction: translation from preclinical to clinical work. Biol Psychiatry 60: $369-375$.

De QuervaIN DJ. 2006. Glucocorticoid-induced inhibition of memory retrieval: implications for posttraumatic stress disorder. Ann N Y Acad Sci 1071: 216-220.

De Quervain DJ, Bentz D, Michael T, Bolt OC, Wiederhold BK, Margraf J and Wilhelm FH. 2011. Glucocorticoids enhance extinction-based psychotherapy. Proc Natl Acad Sci USA 108: 6621-6625.

Debiec J, Ledoux JE AND NAder R. 2002. Cellular and systems reconsolidation in the hippocampus. Neuron 36: 527-531.

Duvarci S, NADer K And Ledoux JE. 2008. De novo mRNA synthesis is required for both consolidation and reconsolidation of fear memories in the amygdala. Learn Mem 15: 747-755.

Forcato C, Rodríguez ML, Pedreira ME and MalDONADO H. 2010. Reconsolidation in humans opens up declarative memory to the entrance of new information. Neurobiol Learn Mem 93: 77-84.

García de la TORRe P, Rodríguez-Ortiz CJ, BALDERAS I AND BERMÚdEZ-RATTONI F. 2010. Differential participation of temporal structures in the consolidation and reconsolidation of taste aversion extinction. Eur J Neurosci 32: 1018-1023.

Heifets BD and Castillo PE. 2009. Endocannabinoid signaling and long-term synaptic plasticity. Annu Rev Physiol 71: 283-306.

Hölter SM, Kallnik M, Wurst W, Marsicano G, LUTZ B AND WOTJaK CT. 2005. Cannabinoid CB1 receptor is dispensable for memory extinction in an appetitively-motivated learning task. Eur J Pharmacol 510(1-2): 69-74.

IgAZ LM, VIANNA MR, MEDINA JH AND IZQUIERdo I. 2002. Two time periods of hippocampal RNA synthesis are required for memory consolidation of fear-motivated learning. J Neurosci 22: 6781-6789.

IZQUIERDO I. 1984. Endogenous state dependency: Memory depends on the relation between the neurohumoral and hormonal states present after training and at the time of testing. In: LYNCH G, MCGAUGH JL AND WEINBERGER NM (Eds), Neurobiology of Learning and Memory. New York, Guilford Press, p. 333-350.

IZQUIERDO I. 2006. Freud and the neurobiology of memory. Rev Psiq Rio G do Sul 28: 243-244.

IzQuierdo I. 2011. Memória. Artmed, $2^{\text {nd }}$ ed., Porto Alegre.

Izquierdo I, Bevilaqua LR, Lima RH, Clarke JH, DA Costa JCC AND CAMmarota M. 2008. Extinction learning: neurological features, therapeutic applications, and effect of aging. Fut Neurol 3: 133-141.

IzQUiERdo I, WyrWicka W, SiERra G ANd SEgundo JP. 1965. Établissement de reflexes conditionnés de trace pendant le sommeil naturel chez le chat. Actual. Neurophysiol 6: 277-296.

JANET P. 1906. The major symptoms of hysteria. MacMillan, New York.

Ji J AND MAREN S. 2007. Hippocampal involvement in contextual modification of fear extinction. Hippocampus 17: 749-758.

Kamprath K, Marsicano G, Tang J, Monory K, BISOGNO T, Di Marzo V, LUTz B AND WOTJAK CT. 2006. Cannabinoid CB1 receptor mediates fear extinction via habituation-like processes. J Neurosci 26(25): 66776686.

KRAJEhPOUR RA AND ZARRINDAST MR. 2009. The amygdala modulates morphine induced state dependent retrieval via muscarinic acetylcholine receptors. Neuroscience 160: 255-269.

LAFenÊtre P, Chaouloff F AND Marsicano G. 2007. The endocannabinoid system in the processing of anxiety and fear and how CB1 receptors may modulate fear extinction. Pharmacol Res 56(5): 367-381.

Likhtik E, Popa D, Apergis-Schoute J, Fidacaro GA AND PARÉ D. 2008. Amygdala intercalated neurons are required for expression of fear extinction. Nature 454: 642-645.

MCGAugh JL. 2000. A century of consolidation. Science 287: $248-351$ 
MILAD MR AND QUIRK GJ. 2002. Neurons in medial prefrontal cortex signal memory for fear extinction. Nature 420: 7-74.

Milad MR, Wright CI, ORR SP, PITMAN RK, QUiRK GJ AND RAUCH SL. 2007. Recall of fear extinction in humans activates the ventromedial prefrontal cortex and hippocampus in concert. Biol Psychiatry 62(5): 446-454.

Milekic MH And Alberini CM. 2002. Temporally graded requirement for protein synthesis following memory reactivation. Neuron 36: 521-525.

Monfils MH, Cowansage KK, Klann E and LedouX JE. 2009. Extinction-reconsolidation boundaries: key to persistent attenuation of fear memories. Science 324 : 951-955.

MYSkiW JC, FiorenzA NG, IZQUiERdo LA AND IZQUIERDO I. 2010. Molecular mechanisms in hippocampus and basolateral amygdala but not in parietal or cingulate cortex are involved in extinction of one-trial avoidance learning. Neurobiology of Learning and Memory 94: 285-291.

Nader K, Schafe GE and Ledoux JE. 2000. Fear memories require protein synthesis in the amygdala for reconsolidation after retrieval. Nature 416: 722-726.

Nemiah JC. 1985. In Comprehensive Textbook of Psychaiatry, IV. Kaplan HI and Sadock BJ (Eds), Williams \& Wilkins, Baltimore, p. 894-942.

Orr SP, Milad Mr, Metzger LJ, Lasko NB, GilbertSON MW AND PITMAN RK. 2006. Effects of $\beta$-receptor blockade, PTSD diagnosis, and explicit threat on the extinction and retention of an aversively conditioned response. Biol Psychol 73: 262-271.

PaVlov IP. 1956. Conditioned Reflexes. New York, Dover.

Pérez-Cuesta LM, Hepp Y, Pedreira ME and MalDONADO H. 2007. Extinction memory in the crab Chasmagnathus: recovery protocols and effects of multi-trial extinction training. Learn Mem 14: 101-108.

Puighermanal E, Marsiano G, Busquets-Garcia A, Lutz B, Maldonado R and Ozaita A. 2009. Cannabinoid modulation of hippocampal long-term memory is mediated by mTOR signaling. Nat Neurosci 12(9): 1152-1158.

Quevedo JL, Vianna MrM, Roesler R, De-Pares F, IZQUIERDO I AND RosE S. 1999. Two time windows for anisomycin-induced amnesia for inhibitory avoidance training in rats: Protection from amnesia by pretraining but not pre-exposure to the task apparatus. Learn Mem 6: 600-607.

Quirk GJ, Paré D, Richardson R, Herry C, Monfils MH, SCHILlER D AND ViCENTIC A. 2010. Erasing fear memories with extinction training. J Neurosci 30: 1499314997.

RESCORLA RA. 2001. Retraining of extinguished Pavlovian stimuli. J Exp Psychol Anim Behav Process 27: 115-124.

RESCORLA RA. 2004. Spontaneous recovery. Learn Mem 11: 501-509.

Ressler KJ, Rothbaum BO, TAnnenbaum L, AnderSON P, GRAAP K, Zimand E, Hodges L AND DAVIS M. 2004. Cognitive enhancers as adjuncts to psychotherapy: use of D-cycloserine in phobic individuals to facilitate extinction of fear. Arch Gen Psychiatry 61: 11361144.

Rossato Ji, Bevilaqua LR, IzQuierdo I, Medina JH AND CAMmarota M. 2010. Retrieval induces reconsolidation of fear extinction memory. Proc Nat Acad Sci USA 107: 21801-21805.

Rossato Ji, Bevilaqua LR, Medina JH, IzQuierdo I AND CAMMAROTA M. 2006. Retrieval induces hippocampus-dependent reconsolidation of spatial memory. Learn Mem 13: 431-441.

Rossato Ji, Bevilaqua LR, Myskiw JC, Medina JH, IZQUIERDO I AND CAMMAROTA M. 2007. On the role of hippocampal protein synthesis in the consolidation and reconsolidation of object recognition memory. Learn Mem 14: 36-46.

SARA SJ. 2000. Strengthening the shaky trace through retrieval. Nature Rev Neurosci 1: 212-213.

Schiller D, Monfils MH, Raio CM, Johnson DC, LE DouX JE AND PHELPS EA. 2010. Preventing the return of fear in humans using reconsolidation update mechanisms. Nature 463: 49-53.

Sher L And Vilens A (Eds). 2010. Neurobiology of PostTraumatic Stress Disorder. New York, Nova, 376 p.

Szapiro G, Galante JM, Barros DM, LeVi De Stein M, VIANNA MRM, IZQUIERDO LA, IZQUIERDO I AND MEdinA JH. 2002. Molecular mechanisms of memory retrieval. Neurochem Res 27: 1491-1498.

Szapiro G, Vianna Mr, McGaugh JL, Medina JH AND IZQUIERDO I. 2003. The role of NMDA glutamate receptors, PKA, MAPK, and CAMKII in the hippocampus in extinction of conditioned fear. Hippocampus 13(1): 53-58. 
Vianna MRM, Szapiro G, McGaugh JL, Medina JH AND IZQUIERDO I. 2001. Retrieval of memory for fearmotivated training initiates extinction requiring protein synthesis in the rat hippocampus. Proc Nat Acad Sci USA 98: 12251-12254.
Viola H, FURMAN N, IZQUiERdo LA, ALONSO MA, Barros DA, de Souza MA, Medina JH ANd IZQUIERDO I. 2000. Phosphorylated cAMP response element-binding protein as a molecular marker of memory processing: Effect of novelty. J Neurosci 20: RC112. 